\title{
Projekt børnekulturkonsulent
}

\section{Af Pernille Schaltz}

Biblioteksstyrelsen har bidraget aktivt til de analyser, der ligger bag redegørelsen "Børn og Kultur"s tanker på folkebiblioteksområdet. Ideen om regionale børnekulturkonsulenter med base i centralbiblioteksregi opstod under forarbejdet med et høringssvar som Biblioteksstyrelsen afgav i forbindelsen med Kulturministeriets udarbejdelse af redegørelsen "Børn og Kultur". Repræsentanter fra biblioteksvæsnet foreslog at den enkelte kommune fik en børnekulturkoordinator med base på folkebiblioteket, og da redegørelsen blev offentliggjort i 1999, blev folkebiblioteket nævnt som et muligt hjemsted for opgaven.

På denne baggrund udarbejdede centralbibliotekerne og Biblioteksstyrelsen en projektbeskrivelse, og i december 1999 iværksættes forsøget på otte centralbiblioteker i foreløbigt et år. Ideen om centralbiblioteket som stifinder og støttefunktion på det børnekulturelle område er ikke ny, men det er første gang ideen afprøves. Den konkrete børnekulturkonsulentfunktion er endvidere omtalt i Forslag til lov om Biblioteksvirksomhed, som på børneområdet delvist bygger på visionerne i redegørelsen "Børn og Kultur".

Følgende centralbiblioteker deltager i projektet; Københavns Kommunes Biblioteker, Gentofte Bibliotekerne, Helsing ør Kommunes Biblioteker,
Biblioteket for Vejle By og Amt, Herning Centralbibliotek, Århus Kommunes Biblioteker, Viborg Centralbibliotek og Det Nordjyske Landsbibliotek. Fors $\varnothing$ get er bygget op om de otte regionale fors $\varnothing \mathrm{g}$ under ledelse af den enkelte centralbibliotekar. Biblioteksstyrelsen har ansvaret for det samlede projekt, som er etårigt og som støttes $\emptyset$ konomisk af Centralbibliotekspuljen og Udviklingspuljen for folke- og skolebiblioteker.

Projektets overordnede mål er knyttet til de kulturpolitiske målsætninger der er formuleret i redegørelsen "Børn og Kultur", og er startet udfra ideen om, at det er afgørende at folkebibliotekerne engagerer sig i implementeringen af "Børn og Kultur", og afsøger de forskellige roller i den kommunale og amtslige debat om, hvordan man konkret sikrer alle børn optimale muligheder. Fokus har flyttet sig fra den enkelte institution til det aktuelle børnekulturelle værdisæt og afsløret behovet for at samarbejde på tværs af institutioner og faggrupper for at skabe helhed og dermed bedre vilkăr for børn.

Projektet skal afdække hvorledes børnekulturkonsulentens støttefunktioner $\mathrm{i}$ forhold til den amtslige kulturpolitik og de kommunale folkebiblioteker kan fremme intentionerne i "Børn og Kultur". Amterne skal støtte det kommunale udviklingsarbejde og centralbibliotekerne skal 
støtte de kommunale folkebiblioteker i at udvikle nye metoder i det børnekulturelle arbejde, samtidig med at folkebibliotekets personalemæssige potentiale i det lokale/regionale børnekulturelle udviklingsarbejde afdækkes.

Børnekulturkonsulenten i centralbiblioteksregi har to fokuspunkter. Det første er amtets børneorienterede kulturliv, hvor konsulenten skal indgå i amtets udviklingsarbejde på det børnekulturelle felt, f.eks. ved at st $\varnothing t t e$ amtets arbejde for børn og kultur, bidrage med ekspertise til udvikling af tværfaglighed, mm. Folkebibliotekerne kan medvirke til udvikling af tværfaglig baseret ekspertise og viden på områder, hvor biblioteket i forvejen har kompetencer.

Det andet fokuspunkt er folkebibliotekerne i amtet, hvor konsulenten skal støtte de kommunale folkebiblioteker i udviklingen af metoder og strategier i forhold til det kommunale arbejde med børnekulturen, ved f.eks. at opsamle erfaringer og samstemme strategier på amtets folkebiblioteker. I kommunen skal konsulenten støtte det kommunale folkebiblioteks synligg $\varnothing$ relse og aktive arbejde med "Børn og Kultur", mens det stadig er det lokale folkebibliotek der skal handle i forhold til børnene, andre faggrupper og politikere. En strategi kan være, at det lokale folkebibliotek, hvis der er mulighed herfor, kan byde ind på rollen som kommunal børnekulturkoordinator. Det vil være denne lokale koordinator der fungerer i kommunen og samarbejder med både lokale voksne politikere, embedsmænd og kulturarbejdere, samt fungere som talsmand for de lokale børn.

Projektets primære målgruppe er de 0-14-årige børn og underst $\varnothing t t e l s e$ af deres identitetsdannelse og deres aktive tilgang til kulturen og muligheder for at udtrykke sig vha. kulturen. Men den regionale børnekulturkonsulents samarbejdspartnere er primært voksne i politiske og faglige netværk samt repræsentative fora i amtet. Derfor bliver den amtslige børnekulturkonsulents arbejde primært synlig gennem børnenes nære voksne og deres initiativer, metoder og strategier.

Projektet startede i februar 2000, og der arbejdes p.t. på de deltagende centralbiblioteker med modeller for analyser af det kommunale og amts- lige børneorienterede kulturliv, organisering og styring af det enkelte regionale projekt samt opbygning af netværk og kompetenceudvikling.

I Århus og Vejle Amt hvor Vibeke Tillemann, ledende børnebibliotekar ved Ebeltoft Bibliotek, og Jim Højbjerg, ledende børnebibliotekar på Biblioteket for Vejle By og Amt, er børnekulturkonsulenter, indledes projektet med en besøgsrunde på amtets folkebiblioteker. Formålet er at diskutere børnebibliotekets muligheder set i lyset af den børnekulturelle redegørelse, at kortlægge hvilke ting der sker i regionen på feltet børn og kultur, samt at danne et billede af hvordan regionens biblioteker organiserer sig i lokalsamfundene. Endvidere skal bibliotekernes $ø$ nsker og ideer på området opsamles.

Vibeke Tillemann sender før sit besøg på de lokale folkebiblioteker en checkliste, som skal danne udgangspunkt for samtalen med den lokale biblioteksleder.

Det drejer sig om punkter som:

- orientering om biblioteket og kommunen generelt

- planer om nye tiltag i forhold til den børnekulturpoltitiske redegørelse

- lokale netværk i kommunen på området børn og kultur

- børnekulturpolitiske målsætninger i kommunen

- forventninger til Vibeke Tillemanns rolle som børnekulturkonsulent. Ønsker om initiativer

- $\varnothing n s k e r$ om kurser/kompetenceudvikling

- hvor man ser muligheder i kommunen

- om der i kommunen findes igangværende projekter og/eller lokale "ildsjæle"/ressourcepersoner

Ved at sende en checkliste før samtalen er det velforberedte biblioteksledere, som allerede har taget stilling til hvad de vil have og hvad der skal ske på det børnekulturelle område på deres lokale bibliotek, som Vibeke Tillemann møder på sin rundtur. Og de tanker og ideer kan bruges i det videre arbejde på det enkelte lokale bibliotek. At Vibeke Tillemann udelukkende mødes med de lokale folkebibliotekers ledere, bunder $\mathrm{i}$ at det efter hendes mening er biblioteksledernes ansvar 
både at iværksætte arbejdet med "Børn og Kultur", at skabe plads i organisationen til det børnekulturelle arbejde, samt at inspirere alle medarbejdere på biblioteket til udviklingsarbejdet. Men det er stadig den enkelte bibliotekar der aktivt skal arbejde videre og investere sig selv for at udvide bibliotekets børnekulturelle platform.

Biblioteksledernes ejerskab gør det internt legitimt at prioritere det børnekulturelle arbejde. Og det er kun hvis man opnår et ejerskab hos lederne, at der vil ske en udvikling på området. Hun understreger at hele bibliotekets personale skal være med i udviklingsprocessen og arbejdet med børnekulturen, og at personalet må praktisere et medansvar for det samlede bibliotek.

Det er også biblioteksledernes ansvar at profilere biblioteket udadtil overfor kommunens embedsmænd og politikere, at fortælle om bibliotekets $\emptyset$ nsker og kompetencer på børneområdet og præsentere måder og skitser på det børnekulturelle område. Derved bliver der lokal politisk fokus på folkebibliotekets og bibliotekarernes potentiale i det kommunale og regionale udviklingsarbejde. Det drejer sig om at få, f.eks. ved at afholde en lokalkonference, et fælles sprog og reference blandt biblioteker, politikere og embedsmænd i kommunen, og blive accepteret som aktør på den amtslige og kommunale arena. Men dette er altså forudsat, at bibliotekslederne føler et ejerskab for projektet, og er villige til at investere i det børnekulturelle arbejde.

Vibeke Tillemann fortæller at bibliotekslederne som oftest er meget motiverede ledere, som også er meget interesserede $i$ at profilere deres bibliotek $\mathrm{i}$ forbindelse med den fokus der er på børn både politisk og på samfundsplan. Efter hendes mening er redegørelsen en gave til børnebibliotekerne, bl.a. fordi den har flyttet biblioteksledernes fulde opmærksomhed over på børn og kultur.

Der er stor forskel på de enkelte kommuner i amtet $\mathrm{i}$ forhold til prioritering af biblioteksvæsnet, $\mathrm{i}$ forhold til det lokale biblioteks prioriteringer, i forhold til det lokale børnekulturelle liv og i forhold til hvilke samarbejdspartnere bibliotekerne har i lokalsamfundet. Men uanset dette har alle biblioteker, små og måske ressourcesvage som store, allerede et stort uformelt børnekulturelt netværk i kommunen, og efter Vibeke Tillemanns mening er udfordringen på det enkelte bibliotek $\mathrm{nu}$, at dette uformelle netværk formaliseres. B $\varnothing \mathrm{r}$ nebibliotekerne har altså allerede en platform i det børnekulturelle arbejde som nu, for at opfylde målsætningerne i Børn og Kultur, skal formaliseres. Bibliotekerne skal altså samtale og koordinere mere struktureret og formelt med deres samarbejdspartnere. Det er dét den egentlige opgave for børnebibliotekerne nu består i.

Jim Højbjerg, som er børnekulturkonsulent i Vejle Amt mener at det nu er blevet lettere at arbejde på børnebiblioteket og at være børnebibliotekar, fordi det arbejde man ude på børnebibliotekerne allerede har udført i mange år, nu bliver synliggjort. Det paradigmeskift som der er sket i forhold til børn og barndomsopfattelser, er efter hans mening en fordel for og en gave til børnebibliotekarerne som, efter mange år hvor lærere og pædagoger har haft "patent" på børnene, nu har fået en "ret" til børnene, idet det nu er børnebibliotekarernes kompetenceområder, kunst, kultur og litteratur, der er i fokus på samfundsplan.

Efter hans mening består udfordringen også ude på de lokale biblioteker $\mathrm{i}$ at formalisere de netværk man allerede har internt i kommunen, samt at sprede dette netværk op på amtsplan. For biblioteket er allerede med som krumtap. Han understreger at det stadigvæk er væsentligt at børnebiblioteket hele tiden selv sørger for at blive involveret i det lokale børnekulturelle arbejde. Og pga. forskellene i det lokale kulturliv, er det de lokale biblioteker der selv skal definere deres samarbejdspartnere og hvilke børnekulturelle foreninger og institutioner der skal samarbejdes og koordineres med.

I Vejle Amt vil man lave et amtsligt børnekulturelt samråd hvor det er meningen at børnebiblioteket også ude i kommunerne skal påtage sig rollen som sekretær i rådet. Efter hans mening, er det vigtigt at mødes om noget konkret, noget praktisk, en stor fælles ting, som så bliver underinddelt i kommunerne og spredt ud i de kommunale institutioner. Når børnebiblioteket får sekretærfunktionen i sådanne børnekulturelle samråd, er de pr. auto- 
matik med i og udgangspunkt for det lokale børnekulturelle arbejde.

I Århus Amt har man valgt et stifinderprojekt med at udvikle biblioteket som et IT-eksperimentarium for børn. Man planlægger at lave projektet "Chatnat" på bibliotekerne for alle børn i 10-14års alderen i amtet. Ideen er at alle børn i amtet skal chatte sammen på samme tid. Alle folkebiblioteker i amtet deltager og er begejstrede for ideen. Efter Vibeke Tillemanns mening er det fordi projektet er overskueligt og afsluttet.

Både Vibeke Tillemann og Jim Højbjerg ser børnekulturredegørelsen og projekt børnekulturkonsulenter som en indsprøjtning og en inspiration til biblioteksvæsnet, som vil påvirke fremtiden. Jim Højbjerg tror at børnebibliotekerne også når projektet er slut vil fortsætte deres arbejde med børn og kultur og med koordineringsarbejdet. Vibeke Tillemann ser projektet som en start på en ikke forudsigelig fremtid. Det børnekulturelle arbejde på biblioteket er en kontinuerlig proces som hele tiden vil være i udvikling. Biblioteket vil være med i denne udvikling.

De tror begge at folkebiblioteket som fysisk sted bliver vigtig $\mathrm{i}$ fremtiden. $\mathrm{B} \emptyset$ rnebiblioteket bliver et mødested med fred og med fokus på det mel- lemmenneskelige møde, som vil fylde meget $\mathrm{i}$ børns liv. Folkebiblioteket og dets børneafdelinger har potentialer i det regionale børnekulturelle udviklingsarbejde og i børns liv. Børnebibliotekarerne skal fortsat turde involvere sig i og bruge tid på børnene og de unge - det er jo også dét, der gør det sjovt og spændende at være børnebibliotekar.

Følg med i projektet i Århus Amt på Internetadressen:

http://www.aakb.dk/amt/kulturkonsulent/ index.htm

\section{Litteratur}

Biblioteksstyrelsen; Børn og kultur: Regionale børnekulturkonsulenter. Biblioteksstyrelsen, Kbh. 2000. Pjece.

Buchhave, Bente; Børnekulturkonsulenter $i$ centralbiblioteksregi in.: Nyt fra Nyhavn. Biblioteksstyrelsen orienterer nr. 1 april 2000. Biblioteksstyrelsen Kbh. 2000. 